\title{
Technology and the Predicament of Time in Don DeLillo's Cosmopolis
}

\author{
Jun Wang \\ Shanghai International Studies University, China
}

\begin{abstract}
Based on a close reading of Don DeLillo's Cosmopolis, the concept of time has been explored from three perspectives: the evacuated now, the unreturnable past and the lost future. Great emphasis is put on the influences global capital market has on the perception of time. The predicament of time has been deeply influenced by the mechanism of the acceleration caused by the chatic financial market and influences on subjectivity in the financial storm which everyone has been wrapped in.
\end{abstract}

Index Terms-Don DeLillo, Cosmpolis, technology, time

\section{INTRODUCTION}

Born in Bronx, Don DeLillo was brought up during the Great Depression of America. It was as well a time of early cold war, gripped by the imposing existence of nuclear threats. Therefore, unlike his contemporary writers Thomas Pynchon and Donald Barthelme, Don DeLillo, approaches American culture from the perspective of an outsider. Since the publication of Americana in 1971, Don DeLillo (1934-) has published sixteen novels, one collection of short stories and seven plays and has received worldwide recognition as one of the most important contemporary American writers. In 2015, he received the Medal for Distinguished Contribution to American Letters from the National Book Foundation. DeLillo's writing carries an insightful and consistent observation about contemporary American society, involving violence, terror and war in post-war America, as well as popular culture and daily life.

After 2000, DeLillo novels have demonstrated a minimal style with shorter sentences, fewer numbers of characters and more concise plotting. But the most noteworthy transformation lies in his thinking about time, besides the postmodern use of time and repeated attempts to explore a state of untimeliness. In his new-century writings, the manipulation of technology, the speed of social development, the mass media and economic turbulence are all the elements that determine the momentum of time. However, the study of time in Don DeLillo's novels, especially in his new-century novels, has not been given adequate attention from critics. The paper chooses DeLillo's Cosmopolis to examine the influence of technology on the predicament of time.

Cosmpolis is, in many ways, the emblematic novel of DeLillo's response to 9/11attacks. It was written before the event and in this sense, the prophetic nature of DeLillo's analysis cannot be neglected. Unlike another prophetic novel Mao II which has been interpreted as anticipation of the rise of fundamentalist terrorism that exists within our world, Cosmpolis is prophetic in the light of revealing a disastrous interlock between time and technology. In December 2001, shortly after the 9/11 attacks, DeLillo published an essay entitled "In the Ruins of the Future: Reflections on Terror and Loss in the Shadow of September" providing an insightful observation of the transformative chaos of the country. He writes, "It is the high gloss of our modernity. It is the thrust of our technology... It is the power of American culture to penetrate every wall, every home, life, and mind."(DeLillo, 2001: 33) ${ }^{1}$ In the aftermath of September 11th, 2001, America is experiencing a dizzying convergence of Don DeLillo's most frightening themes. He writes the physical displacement of thousands of New Yorkers, and the spiritual displacement of millions of Americans; he writes the renewed apocalyptic fear and paranoia. The relationship between technology and time plays a crucial role in the era of global capital, global terrorism and advanced technology.

\section{The Evacuated Now: CAHOOTS OF TeChNOLOGy AND CAPITAL}

Cosmopolis, DeLillo's only novel devoted to the portrayal of American financial market, penetrates New York City, the financial heart of global capital at the turn of the new millennium. The novel tells a story of Eric Packer, a 28-year-old billionaire currency trader in Wall Street who made an impulsive decision to get a haircut one day in April, 2000. The crosstown route from Eric's luxurious residence near the UN headquarter to the abandoned warehouse in the eleventh avenue was seamed with senseless violence and deliberate acts of terrorism. As an epitome of modern chaos, the novel encapsulates modern brutality and banality into one single day and emphasizes that in the globalization of electronic capital, "we need a new theory of time" (DeLillo, 2003, p.86).

The chief reason for the necessity of "a new theory of time" lies in the cahoots of technology and capital which unavoidably results in the predicament of time which evacuates now and reality itself. Underneath the fact that "We die

\footnotetext{
${ }^{1}$ Don DeLillo. "In the Ruins of the Future: Reflections on Terror and Loss in the Shadow of September". Harper's. September 2001: 33.
} 
every day"( DeLillo, 2003, p.45) lies a deep ontological perception-we are our own negation and we are bound to nihility and death. A typical example is the collapse of financial market which teaches us an instant shift, rather than a gradual one has overthrown all the preview rules and paradigms and takes control of every single moment of our life.

"The interaction between technology and capital. The inseparability" (DeLillo, 2003, p.23). With the urbanization of capitalism, urban people are caged in the fierce and stinging tension inwardly, and outwardly. The tension basically grows out of technological innovation and capital globalization. It has been so strong that it engulfs modern life both temporally and spatially.

Technology has changed the way people perceived the world. "The technology...would be the master thrust of cyber-capital, to extend the human experience toward infinity as a medium for corporate growth and investment, for the accumulation of profits and vigorous reinvestment" (DeLillo, 2003, p.207). The dominance of technology engenders complete shift in temporality, in which the past and the future collapse in, rendering in the present eternal, which is different from the concept "now". It refers to the limitlessness of time, or timelessness. In DeLillo's new book, Zero K, the concept of timelessness becomes ultimately thematic: acceleration of time denies possibility of history and time itself becomes nihilistic.

DeLillo quotes Zbigniew Herbert's poem "Report from the Besieged City" as an apocalyptic illustration of the future at the door of a new millennium. In this poem, "I" was assigned to make a chronological record of a war-torn and then abandoned city. I decided to write in the rhythm of weeks: "Monday: stores are empty a rat is now the unit of currency" (Herbert, 2007, p.416). In Cosmopolis, "rat" substitutes many kinds of currencies and is a metaphor of irrationality in the global financial market. It echoes the "specter haunting the world...the specter of capitalism" (DeLillo, 2003, p.96) and satirizes the dystopian reality at the turn of a new century. "The haunting is not so much a figment of the past but an anticipation of the inevitable commodification of whatever emerges in the real world" (Martina, 2015). In this sense, money has lost its narrative quality which means money can neither trace back to its past nor conceive its future. Ironically, though deprived of its identity, money creates time. This contradiction is one of the reasons for modern predication. This paper aims to analyze the mournful predicament of time in the new-millennium. An emphasis is put on the cahoots between technology and capital for the immense influence on people's perception of time.

In Cosmopolis, Eric Parker resides in the eye of financial storm and suffers severe mental stress, incapable of working out a meaning for life. An extravagant way of life is nothing but a reflection of inner anxiety. People carve for material possessions which could have been done without to release the tension from inner world. Eric owned an apartment of forty-eight rooms which he equipped lap pool, card parlor, gymnasium, shark tank and screening room. Speed is undeniably one of the elements posing pressure on people's mental state. He had two private elevators. "One is programmed to play Satie's piano pieces and to move at one-quarter normal speed" (DeLillo, 2003, p.29). The reason why he uses the slow elevator which even brings hatred from other people is that it helps settle the unsettled mood.

Ultimately, Parker decides to follow the impulse of having a haircut in the barber's where his late father was also a frequent. Once he starts his journey, collages of public violence are incredibly witnessed from within his white limousine. Self-awareness awakes in a gradual way. But DeLillo does not stop his story at the awaking of Parker's perception of life; he aims to explore more. As an ex-employee of the super capitalist becomes a constant threat to his life, death seems to be the destination of Eric's one-day journey.

In this sense, haircut is more like a ritual than a mere impulse---a ritual for an escape of present predicament. But where exactly does the escape lie in? DeLillo embeds an escape in his protagonist's digital existence. Does it suggest that technology provides a solution to people's mental predicament? DeLillo's philosophical thinking tells us the answer is never simple: the end is an end without end, as in Waiting for Godot. Efforts put to looking for a runaway from modern dilemma eventually turn out to be self-deceptive. Just as written in the end of the novel, "He is dead inside the crystal of his watch but still alive in original space, waiting for the shot to sound."

The biggest pandemonium on Packer's haircut journey could be the anti-globalization demonstration which is so destructive that it brings about conflicts between demonstrators and the police. Kinski sees the destructive urge as the hallmark of capitalist thought, because old markets must be re-exploited. The temporal division between the old and the new is the arrival of the new millennium. The destruction goes so far that protesters even set off bombs outside the investment bank.

Cosmopolis portrays a world in which one could become the most powerful investor by quickly establishing a digital finance model. Eric Packer is one of them and he soon has connection with Russian tycoons and even American president. Cosmopolis dramatizes the international currency markets that Eric Packer has manipulated to become the most powerful investor on the planet. Capital is the leading stimulation on urban people's mental state and technology is the conspirator. The inseparable two see each other grow with and for the other. Hand in hand, they build up the illusion of capitals. Eric Packer makes his money through international currency exchange. He studies the flow of currency information with the aid of advanced communications technology. The transcendence of real world has induced the obsolescence of time and space when finance gains momentum in accelerated dynamics of instability.

\section{The UnReturnable Past: AcCeleration OF Modern Life}

The anachronistic quality of time overwhelms the characters with a sense of futility. "... time is a corporate asset now. It belongs to the free market system. The present is harder to find... The future becomes insistent. Therefore, something 
will happen soon, maybe today. To correct the acceleration of time. Bring nature back to normal, more or less" (DeLillo, 2003, p.79). The whole novel, condensing a string of sensational happenings into one day, is manifesting the consequence of the acceleration of modern life. It is like a symphony full of fast tempo, epitomizing irrationality and anxiety in the fully capitalized era.

DeLillo ever described the genesis of Cosmopolis: "I started out simply with the idea of letting my protagonist drive across town in one day, a person who is already living in the future and fails to notice how susceptible he is to the destructive mechanisms of the present" (Gourley, 2013, p.38). In this novel, future impinges on the present which can be manifested primarily through the high-tech environment Packer can't live without. Take Packer's custom-made Limo which is also his important workplace, "There were medleys of data on every screen, all the flowing symbols and alpine charts, the polychrome numbers pulsing" (DeLillo, 2003, p.13).

Meanwhile, the past keeps impinging on the present. Packer's limousine carried him to the barber's where his childhood memory resided. The typical ordinary but harmonious family story makes sharp contrast with Packer's present life. The transient warmth and tranquility in his short stay counterbalances the pandemonium during the day. Meriting some comparison with James Joyce's Ulysses, Cosmopolis literally tells a story of one-day effort to correct over-accelerated time. Eric Parker has a mobile office equipped with advanced digital devices---his limousine which is armor-plated, decorated with marble floors and fitted with cameras enabling him to get a panorama from its interior. But we read his inner calling for an ordinary life in the very beginning of the story:

He imagined the whores were all fled from the lamplit corners by now, duck butts shaking, other kinds of archaic business just beginning to stir, produce trucks rolling out of the markets, news trucks out of the loading docks. The bread vans would be crossing the city and a few stray cars out of bedlam weaving down the avenues, speakers pumping heavy sound (DeLillo, 2003, p.7).

The ideal life in Packer's sub consciousness was not about bulk of currency trade, or social gregarious upper-class social gathering. His ordinary family background deep buried a yearning for a less-stressed common life. However, memory did not save him from mental fidgety. Packer left in the middle of the haircut and returned to the fury of life. His rise-up to be a financial giant was ironically a token of the overnight wealth because of the insanity of capital market.

The structure of Cosmopolis consists of four chapters and two interchapters. The narration starts from Packer's luxury triplex. Once getting on his limousine, he begins his way to get a haircut. But the common goal turns out to be a journey interrupted repeatedly by planned meetings and encounters. The frequent change of characters in Eric's car resemble a performance of modern capital collapse and no matter what they do, these characters function to remind Eric about an endangered future. The seemingly-random appearance of characters including his director of technology, chief currency officer etc., makes a cumulative effect. Minor anachronisms gather along the novel's course and move toward some final event. For instance, Vija reminds Eric the necessity of a new time theory, because technology accelerates time and the future is already in the present.

Efforts put to looking for a runaway from modern dilemma eventually turn out to be self-deceptive. Just as written in the end of the novel, "He is dead inside the crystal of his watch but still alive in original space, waiting for the shot to sound." "The interaction between technology and capital. The inseparability" (DeLillo, 2003, p.23). With the urbanization of capitalism, urban people are caged in the fierce and stinging tension inwardly, and outwardly. The tension basically grows out of technological innovation and capital globalization. It has been so strong that it en gulfs modern life both temporally and spatially.

What is the trend of time in this acceleration? We must admit "it is a time which has lost its sense of identity" (Boxall, 2006, p.216). Future, not only impinges on the present, but also penetrates the past. Therefore, what has happened becomes what the future expects. DeLillo gives a very intriguing end to this novel: "He is dead inside the crystal of his watch but still alive in original space, waiting for the shot to sound" (DeLillo, 2003, p.209).

Before September 11, DeLillo writes: "It(technology) tells us that we must live permanently in the future, in the utopian glow of cyber-capital. Because there is no memory there and because this is where everything is faster, better, bigger and simultaneously shapeless, heightless and fleeting" (Gourley, 2013, p.39). In the fast-paced modern society, people's concept about time has been changed. Prehistorically, human beings were free from boundary of time, and on entering the 20th century, people began to show efforts to shake off shackle of clock time in literature by exploring psychological time. Technology could be an indispensable element to lay people under control of time. Nowadays, Money makes time. It used to be the other way around. Clock time accelerated the rise of capitalism. People stopped thinking about eternity" (DeLillo, 2003, p.79). In other words, life, which has been composed of time, is now made up of money. This could well explain modern mental stress.

Meanwhile, inner anxiety disables language, which in fact dissects people connection with the world. Having no one to confide in, Eric, like Oswald in Libra, is another protagonist engulfed by unutterable reality. Silence takes the reign. Inner anxiety makes people shun gaze from others, even eye contact. Eric seldom looks eye to eye with people around him. When Torval reported to Eric the imminent danger of attack, he looked at Eric, which "seemed a massive transgression, violating the logic of coded glances, vocal tones and other gestural parameters of their particular terms of reference" (DeLillo, 2003, p.102).

It is in this inner and outer bewilderment that Packer was thrown into a mental predicament featured by a purposeless 
life and unidentifiable self. The history maker in the capital era, who was supposed to be on the opposite side to the demonstrators did not feel threatened or appalled by what he saw. On the contrary, he "decided to admire this" (DeLillo, 2003, p.88). "Did he envy them? The shatterproof windows showed hairline fractures and maybe he thought he'd like to be out there, mangling and smashing" (DeLillo, 2003, p.92). In this sense, Eric epitomizes the struggle to break the cage of life for freedom, or eternity, if possible.

Mass anxiety should deserve attention as well. It reveals more in terms of people's irrationality faced up with turbulence of financial market and manipulation of digital technology. People are found involved in demonstration, pandemonium, violence, voicing an appeal of justice while not really knowing what they want. Eric encountered the demonstration of anti-globalization, and "saw people running, the vanguard of a crowd, coming this way, and others spilling off the sidewalks, startled and confused, and a styrofoam rat twenty feet tall dodging taxis in the street."( DeLillo, 2003, p.86).

\section{The Lost Future: Digital Death in Cosmopolis}

Don DeLillo finished Cosmopolis nearly when the deathly 9/11 attacks happened. "Terror", DeLillo says, "is now the world narrative, unquestionably." Like many of DeLillo's novels, it is as well a work of death: Arthur Rapp, managing director of the International Monetary Fund, was assassinated in Nike North Korea; Packer's favorite singer Brutha Fez died of chronic cardiac problems; His former friend Nikolai Kaganovich was shot dead just after returning from a trip to Albania Online. But Packer seems to be in an undying death. After he was shot by Benno Levin,

"He wanted to be buried in his nuclear bomber, his Blackjack A. Not buried but cremated, conflagrated, but buried as well. He wanted to be solarized. He wanted the plane flown by remote control with his embalmed body aboard, suit, tie and turban, and the bodies of his dead dogs, his tall silky Russian wolfhounds, reaching maximum altitude and leveling at supersonic dash speed and then sent plunging into the sand, fireballed one and all, leaving a work of art, scorched earth art that would interact with the desert..." (DeLillo, 2003, p.209)

Peter Boxall (2003), as a DeLillo's long-time supporter thinks DeLillo is a timely writer because he has been working towards an ethics of globalization, working to understand how the possibility of global communication relate to the violence of global capital and global terror. He has tried to understand, from the beginning, how an imaginative resistance to or dissent from the tyranny of globalization can find ethical and poetic expression.

It is worth to mention that DeLillo never understates the significance of art in building up human's mentality. He writes about art and artists from his magnum opus Underworld to his latest novel Point Omega, in which art has been an unfailing focus of DeLillo's works saturated with philosophical thoughts. But in Cosmopolis, the function of art to appease and heal one's soul seems to be impotent. Packer reads poems and his wife is a poet. With a good knowledge of fine arts, he chooses his poems, paintings and music to deal with anxiety, but in vain. In fact, about how to tangle the predicament people get bogged down to, DeLillo does not intend to prescribe a cure. Literally, he determines to cure nothing. Packer suffered severe insomnia, which poetry and meditation did not help get rid of the stir of restless identities. "Every act he performed was self-haunted and synthetic. The palest thought carried an anxious shadow" (DeLillo, 2003, p.6).

On the other hand, love, which has been absent from Eric, finally burgeoned in him. Married but living apart, the newly-weds communicated in an awkward and half-mystical way. Among a kaleidoscope of absurd happenings during the one-day journey, Eric met his wife Elise Shifrin three times. Elise thought he was "a dangerous person" and he thought poems Elise wrote were "shit". Because of the colossal property of the poet wife, the motive of Eric's marrying her was taken as suspicious. It looks to be "Two great fortunes. Like one of the great arranged marriage of old empire Europe" (DeLillo, 2003, p.26). With the travel drawing to its closure, Eric clearly realized his love for his wife especially when he met Elise for the third time during an absurd film-making. In the end of his life, he felt missing for Elise, "and wanted to talk to her, tell her she was beautiful, lie, cheat on her, live with her in middling matrimony, having dinner parties and asking what the doctor said" (DeLillo, 2003, p.206). Pitifully, Elise disappeared untraceably and love has not reaching out a helping hand in getting him out of mental predicament.

After he was murdered, Eric was deprived of his social labels in the mortuary and returned to the very natural state of existence as when he emerged in the world_- "Male Z", which implies a complete escape from the highly materialized life and return to a natural state. "He'd always wanted to be become quantum dust, transcending his body mass, the soft tissue over the bones, the muscle and fat. The idea was to live outside the given limits, in a chip, on a disk, as data, in whirl, in radiant spin, a consciousness saved from void" (DeLillo, 2003, p.206). However, there is no simple and final solution to get out the abyss. Just as Eric's leaving the barber's in the middle of the haircut at a strong impulse to leave out of a half-mysterious motive, the returning to an ordinary life has been impossible.

\section{CONCLUSION}

The stagnancy-looking temporality contains a rush of momentums and forces. A persuasive example is the contrast in language between Body Artist and Cosmopolis: the former, as DeLillo's first novel after 2000, has begun to convey a signal of transition in his time philosophy. Cosmopolis was written in a specific moment in the history of American capital, technology and politics. As Boxall suggests it is difficult to imagine a time that does not involve an alienating 
wrench from the dying past towards the unborn future (Boxall, 2013, p.4). Future, not only impinges on the present, but also penetrates the past and what has happened becomes what the future expects. As a weighty contemporary writer, DeLillo's writing reflects the transformation in understanding of time in the transformative moment of history. To write about DeLillo's fiction after the year 2000 does not suggest a fragmentary study of a writer's oeuvre rather, besides a timely concern within American literature.

\section{REFERENCES}

[1] Boxall, Peter. (2003). Don DeLillo: The Possibility of Fiction. New York: Routledge.

[2] Boxall, Peter. (2013). Twenty-First-Century Fiction. Cambridge: Cambridge University Press.

[3] DeLillo, Don. Cosmopolis. New York: Scribner.

[4] Don DeLillo. (2001). In the Ruins of the Future: Reflections on Terror and Loss in the Shadow of September. Harper's. September 2001, pp. 33-40.

[5] Duvall, John. (ed.). (2008). The Cambridge Companion to Don DeLillo. Cambridge: Cambridge University Press.

[6] Gourley, James. (2013). Terrorism and Temporality in the Works of Thomas Pynchon and Don DeLillo. New York and London: Bloomsbury Publishing Plc.

[7] Glen, Thomas. (1997). History, Biography and Narrative. Twentieth Century Literature, 43, pp.107-124.

[8] Herman, David. (ed). (2007). The Cambridge Companion to Narrative. Cambridge: Cambridge University Press.

[9] Herbert, Zeigniew. (2007). The Collected Poems 1956-1998. New York: HarperCollins Publishers.

[10] Kavadlo, Jesse. (2004). Don DeLillo: Balance at the Edge of Belief. New York: Peter Lang.

[11] Sciolino, Martina. (2015). The Contemporary American Novel as World Literature: The Neoliberal Antihero in Don DeLillo's Cosmopolis. Texas Studies in Literature and Language, 57, pp.210-241.

[12] Meyerhoff, Hans. (1955). Time in Literature. Berkeley, Los Angeles and London: California Press.

Jun Wang was born in Dancheng County, Henan Province, China in 1981. She is currently pursuing her PH.D. degree in English Literature in Shanghai International Studies University. Her research interests include postmodernist literature and American literature. 